\title{
Diyette Proteinler, Aminoasitler ve Bazı Diğer Aminli Bileşiklerin Kardiyovasküler Sistem Üzerine Metabolik Etkileri
}

\author{
Elif Uğur, Reyhan Nergiz-Unal * \\ Hacettepe Üniversitesi, Sağllk Bilimleri Fakültesi, Beslenme ve Diyetetik Bölümü, 06100 Ankara, Türkiye
}

\section{A K A L E B İ L G İ S İ}

\section{Derleme Makale}

Geliş 03 Ağustos 2016

Kabul 15 Kasım 2016

Çevrimiçi baskı, ISSN: 2148-127X

Anahtar Kelimeler:

Protein

Amino asit

Aminli bileşikler

Kardiyovasküler hastalıklar

Beslenme

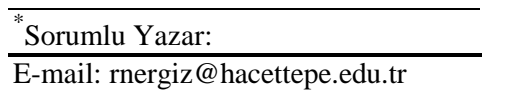

\section{Ö Z E T}

Dünyadaki ölüm nedenleri arasında ilk sırada yer alan kardiyovasküler hastalıkların önlenmesi ve tedavisi için diyet büyük önem arz etmektedir. Kardiyovasküler sistem üzerine etkili beslenme programları genellikle lipid ve karbonhidratlar üzerinde odaklanmışken proteinlerin etkisi göz ardı edilmektedir. Bu nedenle bu derleme; diyetteki proteinlerin, aminoasitlerin ve bazı diğer aminli bileşiklerin kardiyovasküler sağlık üzerine etkilerinin incelenmesi amacıyla yazılmıștır. Hayvansal veya bitkisel kaynaklı proteinler; süt ve süt ürünleri, yumurta, et, tavuk ve balık etleri, baklagiller ve tahıllar gibi besinler farklı protein kompozisyonuna sahip oldukları için kan basıncı ve lipid profilinin regülasyonu üzerine etkileri değişmektedir. Proteinleri oluşturan aminoasitler de protein kaynaklarına benzer olarak kardiyovasküler sistem üzerine farklı etkilere sahiptir. $\mathrm{Bu}$ açıdan kükürtlü aminoasitler başta olmak üzere aromatik aminoasitler, dallı zincirli aminoasitler, arjinin, ornitin, sitrulin, glisin ve glutamin aminoasitleri kardiyovasküler sistemi farklı metabolik yollarla etkilemektedir. Bu kapsamda tek karbon metabolizmas1, hormon sentezi, sinyal yollarının uyarılması ve aminoasitlerin metabolizmaları sonucunda oluşan ara ve son ürünlerin etkileri sayılabilir. Protein ve aminoasitlerin dışında diyetle alınan diğer aminli bileşikler içinde trimetilamin N-oksit, heterosiklik aromatik aminler, polisiklik aromatik hidrokarbonlar ve maillard reaksiyonu ürünleri yer almaktadır. Bu aminli bileşikler genellikle oksidatif stresi, inflamasyonu ve aterosklerotik plak gelişimi tetikleyerek kardiyovasküler hastalıklar için risk oluşturabilmektedir.

Turkish Journal Of Agriculture - Food Science And Technology, 5(1): 71-83, 2017

Metabolic Effects of Dietary Proteins, Amino Acids and The Other Amine Consisting Compounds on Cardiovascular System.

\section{A R T I C LE INFO}

\section{Review articles}

Received 03 August 2016

Accepted 15 November 2016

Keywords:

Protein

Amino acid

Amine compounds

Cardiovascular diseases

Nutrition

* Corresponding Author:

E-mail: rnergiz@hacettepe.edu.tr

\section{A B S T R A C T}

During the prevention and treatment of cardiovascular diseases, first cause of deaths in the world, diet has a vital role. While nutrition programs for the cardiovascular health generally focus on lipids and carbohydrates, effects of proteins are not well concerned. Thus this review is written in order to examine effect of proteins, amino acids, and the other amine consisting compounds on cardiovascular system. Because of that animal or plant derived proteins have different protein composition in different foods such as dairy products, egg, meat, chicken, fish, pulse and grains, their effects on blood pressure and regulation of lipid profile are unlike. In parallel amino acids made up proteins have different effect on cardiovascular system. From this point, sulfur containing amino acids, branched chain amino acids, aromatic amino acids, arginine, ornithine, citrulline, glycine, and glutamine may affect cardiovascular system in different metabolic pathways. In this context, one carbon metabolism, synthesis of hormone, stimulation of signaling pathways and effects of intermediate and final products that formed as a result of amino acids metabolism is determined. Despite the protein and amino acids, some other amine consisting compounds in diet include trimethylamine $\mathrm{N}$-oxide, heterocyclic aromatic amines, polycyclic aromatic hydrocarbons and products of Maillard reaction. These amine consisting compounds generally increase the risk for cardiovascular diseases by stimulating oxidative stress, inflammation, and formation of atherosclerotic plaque. 


\section{Giriş}

İdeal kardiyovasküler sağlık sigaradan uzak durma, normal vücut kütle indeksi, egzersiz yapma durumu ve yeterli ve dengeli bir diyet örüntüsü ile sağlanabilmektedir. Ayrıca Dünya Sağlık Örgütü (WHO), Avrupa Kardiyoloji Derneği (ESC) ve Amerikan Kalp Birliği (AHA) gibi uluslararası kuruluşlara göre bunların yanı sıra kan total kolesterol seviyesi, kan basıncı ve açlık kan glukozu gibi faktörlerin optimal düzeyde olması ile birlikte tanısı konulmuş herhangi bir kardiyovasküler hastalığın olmaması kardiyovasküler sağlık olarak tanımlamaktadır (Perk ve ark., 2012; Shay ve ark., 2015; WHO, 2015).

Uluslararası kuruluşların verilerine göre her yıl 17,5 milyon kişi kardiyovasküler hastalıklar sebebiyle hayatını kaybetmektedir (Perk ve ark., 2012; Shay ve ark., 2015) ve bu sayı dünya çapındaki tüm ölümlerin \%31'ini oluşturmaktadır (Shay ve ark., 2015). Dünya çapında birinci sırada ölüm nedeni olan kardiyovasküler hastalık riskini az miktarda meyve tüketimi, yüksek vücut kütle indeksi, yüksek açlık kan glukozu, yüksek miktarda tuz tüketimi, sert kabuklu kuru yemişlerin az tüketimi gibi beslenme kaynaklı etmenler arttırmaktadır (Perk ve ark., 2012; Shay ve ark., 2015; WHO, 2014; WHO, 2015). Dolayısıyla kardiyovasküler hastalıkların tedavi ve önlenmesinde medikal tedaviye ek olarak diyetin de içerisinde yer aldığ 1 yaşam biçimi değişikliği önem arz etmektedir (Bhupathiraju ve Tucker, 2011).

Kardiyovasküler hastalıkların önlenmesi ve tıbbi beslenme tedavisinde az yağlı süt ürünleri, tam tahıllar, sert kabuklu yemişler (ceviz, findık vb.), tavuk ve balık ile meyve ve sebzelerin tüketimi arttırılırken; yağlı hayvansal kaynaklı besinlerin (kırmızı et, tam yağlı süt ürünleri), rafine şekerli yiyecek ve içeceklerin tüketiminin kısitlanması genel bir beslenme önerisidir (SalehiAbargouei ve ark., 2013). Ancak beslenme programları genellikle lipid ve karbonhidrat alımı üzerine yoğunlaşmakta olup proteinlerin etkisi göz ardı edilmektedir. $\mathrm{Bu}$ nedenle bu derleme; diyetteki proteinlerin, aminoasitlerin ve bazı diğer aminli bileşiklerin kardiyovasküler sağlık üzerine etkilerinin incelenmesi amacıyla yazılmıştır.

\section{Kaynaklarına Göre Diyet Proteinleri ve Etkileri}

Proteinler bitkisel ve hayvansal kaynaklı besinlerin matriksinde bulunmaktadır. Kendilerine özgü aminoasit örüntüsü ve biyolojik aktiviteleri olduğu için kardiyovasküler sağllk üzerine olumlu veya olumsuz etkilere sahip olabilmektedir (Richter ve ark., 2015). Bu konuda yapılan kontrollü çalışmaların meta analizinde yüksek miktarda protein içeren diyetin (toplam enerji gereksiniminin \%27'si) kan kolesterol ve trigliserid düzeylerini düşürerek kardiyovasküler sağlığı geliştirdiği bildirilmiştir (Clifton ve ark., 2009). Diğer yandan başka bir meta analizde ise yüksek miktarda protein içeren diyet (toplam enerji gereksiniminin $>\% 25$, i) tüketiminin obezite ve kardiyometabolik risk faktörlerini düşük miktarda protein içeren diyetle kıyaslandığında arttırdı görülmüştür (Schwingshackl, 2013).

Hayvansal veya bitkisel kaynaklı diyet proteinleri farklı aminoasit ve amin kompozisyonuna sahip oldukları için lipid metabolizmasına etkileri değişebilmektedir (El Khoury ve Anderson, 2013). Proteinlerin lipid metabolizması üzerine etkileri net olmamakla birlikte protein sindirim ürünleri olan biyoaktif peptidler ve sonuçta oluşan bağırsak kaynaklı hormonlar ile ilişkilendirilmektedir. Diyet ile alınan protein ve peptidler bağırsaktan kolesistokinin (CCK), glukagon benzeri peptid 1 (GLP-1), peptid YY (PYY) ve ghrelin gibi inkretinlerin salınımını uyarmaktadır. Bu inkretinler, gastrik ve pankreatik salgıları etkileyerek, mide boşalmasını geciktirerek ve iştah hissini baskılayıp besin alımını azaltabilmektedir. Bu şekilde proteinlerin lipid metabolizmasını da etkilediği bildirilmiştir (Richter ve ark., 2015).

Diyetle alınan protein miktarı artarken karbonhidrat ve yağ içeriği ile enerji alımı azaldığında lipid profili olumlu etkilenmektedir. Ancak diyetin yağ içeriği de önemli bir etken olduğundan dolayı yağglı hayvansal kaynaklı besinlerle protein alımını arttırmak diyette yağ alımını da arttırabilmektedir (El Khoury ve Anderson, 2013). Bu konuda yapılan bir çalışmada insanlarda yüksek protein (\%34; 88,6 g/gün) ve düşük karbonhidrat $(\% 33 ; 86,1$ g/gün) içeren normal yağlı diyetin 9 ay sonunda kan glukoz, toplam kolesterol, düşük yoğunluklu lipoprotein kolesterol (LDL-K) ve trigliserit düzeylerinde anlamlı miktarda düşüsse neden olduğu saptanmıştır (de Luis ve ark., 2015). Ancak proteini yüksek ve yağı az veya normal diyet planlamak zor olduğu için bu diyetlere protein bar takviyelerinin yapıldığı görülmektedir.

Proteinlerin kardiyovasküler sağllk üzerine etkileri net olmamakta birlikte farklı hayvansal ve bitkisel besinler ile alınan proteinlerin ve biyoaktif peptidlerin lipid profili, kan basıncının regülasyonu, inflamasyon ve endotel disfonksiyon gibi kardiyovasküler hastalık belirteçleri üzerine etkileri günümüzde araştırılmaya devam edilmektedir.

\section{Hayvansal Kaynaklı Proteinler}

Hayvansal kaynaklı besinler yüksek miktarda ve iyi kalitede protein içermelerinin yanı sıra doymuş yağ asitleri ve kolesterol içeriği yüksek besinlerdir (El Khoury ve Anderson, 2013). Bu yüzden diyetle bireysel farkl111klar göz önünde bulundurularak gereksinime göre tüketilmesi gerekmektedir (Astrup, 2014; El Khoury ve Anderson, 2013). Hayvansal kaynaklı proteinler kardiyovasküler sağlık açısından süt ve ürünleri, yumurta, balık, kırmızı et ve kümes hayvanları etlerinde bulunan proteinler olarak incelenebilir (Jahan-Mihan ve ark., 2011).

Süt ve süt ürünleri proteinleri: Süt proteinlerinin $\% 80$ 'ini kazein ve \%20'sini whey (peyniraltı suyu) proteinleri oluşturmaktadır (Koury ve ark., 2014; Rice ve ark., 2011). Kazein proteinleri $\alpha_{s^{1}}, \alpha_{\mathrm{s}^{2}}, \beta$ - ve $\kappa$-kazein iken (Jahan-Mihan ve ark., 2011; Koury ve ark., 2014); whey proteinleri $\alpha$-laktoalbumin, $\beta$-laktoglobulin, whey albümini, immünoglobulinler, laktoferrin, laktoperoksidaz ve proteoz-pepton fraksiyonlarıdır (Jahan-Mihan ve ark., 2011).

Whey proteinleri karaciğerde 3-hidroksi-3metilglutaril koenzim A (HMG-CoA) redüktaz enzimini baskılayarak endojen kolesterol sentezini, ayrıca yă 
asitlerinin emilim ve transportunu azaltabilmektedir. Böylece lipid metabolizması üzerinde olumlu etki ederek kardiyovasküler sağlığ 2011). Bu konuda yapılan bir çalışmada 12 hafta süresince Whey proteini (65 g/gün) alımının insanlarda LDL-K ve trigliserit seviyelerini düşürürken, yüksek yoğunluklu lipoprotein kolesterol (HDL-K) ve apolipoprotein-A1 (apo-A1) seviyelerini ise yükselttiği gösterilmiştir (Tahavorgar ve ark., 2015).

Diğer yandan, whey ve kazein proteinleri hidrolizatlarının insülin yanıtını uyararak kan glukozunu azalttığı ve lipid metabolizmasını etkilediği bildirilmiştir (Patil ve ark., 2015). Ayrica kazein proteinleri Whey ile kıyaslandığında sindirim süreleri daha uzun olduğu için gastrointestinal sistemi geç terk ederek iştah hissini baskılayabileceği ve böylece besin alımını azaltarak kronik hastalıklar ile ilişkili olabileceği düşünülmektedir (Koury ve ark., 2014). Kazein ve Whey proteinleri hidrolizatları olan kazokinler ve laktokinler anjiotensin dönüştürücü enzimi (ACE) baskılayarak hem sistolik hem diastolik kan basıncının düşmesini sağlayarak hipertansiyona ve dolayısıyla kardiyovasküler hastalıklara karşı koruyabilmektedirler (Pal ve Radavelli-Bagatini, 2013).

Görüldüğü gibi güncel çalışmalar değerlendirildiğinde kardiyovasküler sistem üzerine etkileri en sık araştırılan süt ve süt ürünleri proteinleri kazeinler, Whey proteinleri ve diğer biyoaktif peptidlerdir (laktokinler ve kazokinler). $\mathrm{Bu}$ peptidlerin lipoprotein ve kolesterol metabolizması, insülin aracılı lipid metabolizması ve besin alımı ile kan basınc1 regülasyonu üzerine etkili olduğu görülmektedir.

Yumurta proteinleri: Yumurta, kas dokusunun korunmasını sağlayan ve protein sentezini uyaran yüksek kalitede protein içeren bir besindir (Andersen, 2015). Yumurta proteinlerini ovoalbumin, ovotransferrin, ovomukoid, ovomusin, lizozim, ovoglikoprotein, ovoflavoprotein, ovomakroglobulin, avidin ve fosfitin oluşturmaktadır (Yu ve ark., 2014)

Yumurta proteinleri genellikle ACE inhibisyonu ile kan basıncını regüle ederek kardiyovasküler sistemi etkilemektedir (Miguel ve Aleixandre, 2006; Yu ve ark., 2014; Zambrowicz ve ark., 2014). Ovotransferrin proteininin hidrolizi ile oluşan tripeptidlerin ACE enzimini inhibe ederek sistolik ve diastolik kan basıncını düşürdüğü, inflamasyonu azaltarak endotel fonksiyonu geliştirdiği güncel bir çalışmada gösterilmiştir (Majumder ve ark., 2015). Ovoalbuminden oluşan biyoaktif bir peptid olan ovokinin oral alındığında vazodilatatör etki ederek kan basıncını düşürebilmektedir. Aynı zamanda ovoalbuminin kimotripsin ile hidrolizi sonucu oluşan hegzapeptidin (Arg-Ala-Asp-His-Phe-Leu) nitrik oksit salınımını uyararak vazodilatasyon sağlayabildiği yayınlanmıştır (Miguel ve Aleixandre, 2006). Ayrıca yumurtada bulunan fosfitinin tripsin ile hidrolizi sonucu oluşan fosfopeptidlerin antioksidan özelliğe sahip olduğu yağ asitlerinin özellikle de linoleik asitin oksidasyonunu inhibe ederek ateroskleroz gelişimini engelleyebildiği de belirtilmiştir (Zambrowicz ve ark., 2014).

Güncel çalışmalar değerlendirildiğinde yumurtanın kardiyovasküler sistem üzerine genellikle ACE'yi inhibe edip kan basıncını regüle ederek yă̆ asitlerinin peroksidasyonunu azaltarak ateroskleroz ve hipertansiyona karşı koruyucu olabileceği görülmektedir.
Et, tavuk ve ballk proteinleri: Kırmızı ve beyaz etler ile balık dünya çapında kabul gören nitelikte kaliteli protein kaynağıdır. Et proteinleri temelde aktin ve miyozin olmak üzere 2 gruba ayrılır. Aynı zamanda troponin, tropomiyozin ve titin proteinleri de bulunmaktadır (Ryan ve ark., 2011).

Kırmizı etlerde bulunan troponin, troponin C, miyozin, aktin ve titin proteinlerinin sindirim sisteminde hidrolizi sonucunda oluşan peptidler ACE'yi inhibe ederek kan basıncını regüle etmektedir (Lafarga ve Hayes, 2014). Ette bulunan ACE inhibitörü peptidler, ACE enziminin aktif bölgesine ya da enzim üzerinde lokalize olan inhibitör bölgeye bağlanıp substratın enzime bağlanmasını engelleyerek vazodilatatör etki gösterebilmektedir (Ryan ve ark., 2011).

Miyozininin sindirimi sonucunda oluşan pentapeptidlerin (miyopentapeptid A ve miyopentapeptid B) ve oktapeptidlerin, kırmızı ette bulunan troponin proteininin hidrolizi sonucu oluşan peptid fraksiyonlarının ve balıkta bulunan aktin proteinlerinin hidrolizi sonucu oluşan peptid fraksiyonlarının ACE'yi inhibe edici etkileri bulunmaktadır (Ryan ve ark., 2011). Tavuk proteinlerinin kan basıncı üzerine etkisinin araştırıldığı bir çalışmada tavuk kollajen protein hidrolizatları içeren diyet tüketiminin hem sistolik hem de diastolik kan basıncını düşürdüğü gösterilmiştir (Kouguchi ve ark., 2014). Avrupa Gıda Güvenliği Otoritesi (EFSA) bazı balık proteinlerinin (palamut) termolizin ile sindirimi sonucu oluşan lösin-lizin-prolin-asparajin-metiyonin peptid fraksiyonunun kan basıncını düşürmede etkili olduğunu rapor etmiştir (EFSA, 2010a).

Bazı balıkların kaslarında bulunan proteinlerin proteolitik enzimler ile hidrolizi sonucu oluşan peptidlerin antioksidan özellikleri bulunmaktadır (Ryan ve ark., 2011) ve bu sayede başta linoleik asit olmak üzere diğer yağ asitlerinin oksidasyonunu engelleyebilmektedirler (Chakrabarti ve ark., 2014; Ryan ve ark., 2011). Aynı şekilde tavuk etinde de antioksidatif etkili peptidler bulunmaktadır (Ryan ve ark., 2011).

Görüldüğü gibi kırmızı et, tavuk ve balık etlerinde bulunan proteinler; kardiyovasküler sistem üzerine bu proteinlerin sindirimi sonucunda oluşan biyoaktif peptidler aracılığı ile etki etmektedir. Genel olarak ACE üzerine olan etkilerine ek olarak oksidan stresi etkileyerek kardiyovasküler hastalık riskini et türüne göre değiştirmektedir.

\section{Bitkisel Kaynakl Proteinler}

Bitkisel kaynaklı besinler proteinlerin yanı sıra diğer makro besin ögelerini, vitaminler ve mineraller gibi mikro besin ögelerini içermektedirler. Ayrıca çözünür ve çözünmez posa için de iyi kaynaktır (Ruiz Ruiz ve ark., 2014). Bitkisel kaynaklı proteinlerin antihipertansif, antiinflamatuar, antihiperlipidemik ve antihiperkolesterolemik etkileri bulunduğu birçok çalışmada gösterilmiştir (García ve ark., 2013; Ruiz Ruiz ve ark., 2014). Bitkisel kaynaklı proteinler soya ve diğer baklagiller ile tahıl proteinlerini içermektedir (Ruiz Ruiz ve ark., 2014).

Baklagil proteinleri: Yapılan çalışmalar incelendiğinde soya fasulyesinin en sık araştırılan baklagil olduğu görülmektedir. Ancak Türkiye'de tüketiminin yüksek olduğu kuru fasulye gibi diğer baklagil 
proteinlerinin hidrolizi ile oluşan glutamat-fenilalanin, izolösin-arginin ve lizin-fenilalanin dipeptid fraksiyonlarının ACE'yi inhibe ederek antihipertansif etki gösterdiği de bilinmektedir. (Malaguti ve ark., 2014). Fasulye ve diğer baklagil proteinlerinin hidrolizi ile oluşan biyoaktif peptidlerin antihipertansif etkilerinin yanında antioksidan etkileri de bulunduğu gösterilmiştir (Dahl ve ark., 2012).

Soya proteinlerinin, özellikle LDL-K ve total kolesterol seviyelerinin düşmesini sağlayarak kardiyovasküler sağlığı olumlu etkilediği EFSA'nın yayınladığı bir raporda bildirilmiştir (EFSA, 2010b). Bir meta analizde ise soya proteini tüketiminin LDL-K ve trigliserit seviyelerini azaltırken HDL-K üzerine anlamlı bir etkisinin olmadığı sonucuna varılmıștır (Saita ve ark., 2015). Amerikan Gıda ve İlaç Dairesi (FDA)'nin 2013 tarihinde yayınladığı gida etiketlemede sağlık beyanı raporuna göre; günlük 25 gram soya alımı 6,25 g soya proteini sağlamaktadır. Düşük doymuş yağ ve kolesterol içeren diyet ile birlikte $6,25 \mathrm{~g}$ soya proteini tüketimi kalp hastalıkları riskini azaltarak kardiyovasküler sağlığ geliştirmektedir (FDA, 2013).

Soya fasulyesi proteinlerinden elde edilen 43 aminoasitli lunasin; kan LDL-K seviyesini düşürücü etkiye sahip olmakla birlikte (Lule ve ark., 2015; Ruiz Ruiz ve ark., 2014; Sacks ve ark., 2006), antihipertansif, antioksidan ve hipokolesterolemik etkileri de bulunan bir polipeptiddir (J. Liu ve ark., 2014). Lunasinin hipokolesterolemik etkisi ya HMG-KoA redüktaz enziminin aktivitesini inhibe edip karaciğerde de-novo kolesterol sentezini baskılayarak ya da LDL reseptör geninin ekspresyonunu arttırıp kan dolaşımında LDL-K seviyesinin düşürerek olabilir. Ayrıca lunasinin LDL reseptörlerinin üretiminde gerekli olan sterol düzenleyici öge bağlayıcı proteininin (SREBP) ekspresyonunu arttırdığı da düşünülmektedir (Lule ve ark., 2015).

Özetle sağlıklı beslenme önerilerinde yer alan baklagillerin yapısında bulunan peptidler kan basıncı ve kolesterol metabolizmasını olumlu yönde etkileyerek kardiyovasküler sağlı̆̆ı koruyabilmektedir.

Tahıl proteinleri: Buğday, mısır ve pirinç gibi tahıl ürünlerinde bulunan daha önce bahsedilen lunasin peptidi, LDL-K ve total kolesterolü seviyesini düşürebilmektedir (Lule ve ark., 2015; Malaguti ve ark., 2014; Ruiz Ruiz ve ark., 2014; Sacks ve ark., 2006). Bu peptidin aynı zamanda tümör nekroz faktör- $\alpha$ (TNF- $\alpha)$ ve interlökin-6 (IL-6) gibi inflamatuar sitokinleri baskılayarak antiinflamatuar etkilere sahip olduğu yayınlanmıştır (J. Liu ve ark., 2014; Malaguti ve ark., 2014). Bu sayede ateroskleroz gibi inflamatuar vasküler hastalık riskini azaltabilmektedir (Malaguti ve ark., 2014).

Tahıllarda proteinlerin hidrolizi sonucu oluşan izolösin-alanin-prolin biyoaktif tripeptidi (Malaguti ve ark., 2014), $\alpha$-gliadin , $\gamma$-gliadin ve $\omega$-gliadin proteinlerinin biyoaktif peptid fraksiyonları (Cavazos ve Gonzalez de Mejia, 2013) ve pirinç proteinlerinin alkalaz enzimi ile hidrolizinden oluşan treonin-glutamin-valintriptofan tetrapeptid fraksiyonu ACE'yi inhibe ederek sistolik ve diastolik kan basıncını düşürebilmektedir (Malaguti ve ark., 2014).

Türkiye'de yüksek miktarda tüketilen tahılların içerdiği proteinler antihiperkolesterolemik etkileri ile kan kolesterol ve lipoprotein seviyelerini regüle edebilmektedirler. Buna ek olarak antiinflamatuar etkileri ile inflamasyonu baskılayarak veya ACE inhibisyonu ile vazodilatasyonu sağlayarak kardiyovasküler sağlığı geliştirebilmektedirler.

\section{Protein Yapısında Bulunan Aminoasitler ve Etkileri}

\section{Kükürtlü Aminoasitler}

Sistein, metiyonin, homosistein ve taurin kükürt içeren aminoasitlerdir ve metabolizmaları birbirleri ile ilişkilidir (Bkz. Şekil 1). Bu aminoasitler glutatyon ve protein sentezi, DNA, RNA ve proteinlerin metilasyonu gibi çeşitli metabolik yollarda birlikte bulunmalarının yanında lipid metabolizması ve vücut kompozisyonunun düzenlenmesinde de rol oynamaktadırlar (Poloni ve ark., 2015).

Kan sistein düzeylerinin artmasının kardiyovasküler sağlığı olumsuz etkileyebildiği düşünülmektedir. Etki mekanizması tam bilinmemekle birlikte kan sistein seviyeleri yüksek olan bireylerde periferal arter hastalıkları ve miyokard infarktüsü gelişim riskinin artığı gösterilmiştir (Glier ve ark., 2014). Sistein ve metiyonin aminoasidinden transmetilasyon metabolik yolu ile sentezlenen homosistein protein sentezine katılmayan kükürt minerali içeren bir aminoasittir ve metilasyon siklüsunda yer alır (Baggott ve Tamura, 2015; Ganguly ve Alam, 2015; Martí-Carvajal ve ark., 2015). Bu metabolik yolda yer alan enzimlerin aşırı uyarılması, sistatyon $\beta$ sentaz enziminin eksikliği veya folat, $B_{6}$ ve $B_{12}$ vitamini gibi ko-faktörlerin eksiklikleri de kan homosistein seviyesini arttırmaktadır (Ganguly ve Alam, 2015). Sağlıklı bir bireyde kan homosistein düzeyi $15 \mu \mathrm{mol} / \mathrm{L}$ üzerine çıması hiperhomosisteinemi olarak değerlendirilmektedir (Ganguly ve Alam, 2015; Poloni ve ark., 2015). Hiperhomosisteinemi durumunda folat ve $B_{12}$ vitamini gibi ko-faktör desteğinin kan homosistein düzeylerini düşürebildiği bilinmektedir (van Dijk ve ark., 2015).

Kan homosistein seviyesi ile ilintili olan glisin aminoasidi, metabolizmada kolin başta olmak üzere farklı yollardan sentezlenmektedir. Glisinin kolinden betain ve sonrasında dimetilglisine dönüşümünde metil grubu homosisteine aktarılarak kan homosistein seviyesini etkilemektedir (W. Wang ve ark., 2013). Kan homosistein seviyesinin yükselmesi kardiyovasküler hastalıklar için risk faktörüdür (Baggott ve Tamura, 2015; Ganguly ve Alam, 2015; Martí-Carvajal ve ark., 2015).

Homosistein kardiyovasküler sistemi farklı yollarla etkilemektedir. Bunlar; vasküler düz kas hücrelerinin proliferasyonu, endotel disfonksiyon, oksidatif hasar, kollajen sentezini arttırma ve arteriyel duvarlardaki bozulma ile olabilmektedir (Baggott ve Tamura, 2015; Ganguly ve Alam, 2015; Martí-Carvajal ve ark., 2015). Ayrıca homosistein mRNA ve vasküler düz kas hücrelerinde C-reaktif protein (CRP)'nin ekspresyonunu uyararak inflamasyonu arttırabilmektedir (Ganguly ve Alam, 2015). Homosisteinin endotel disfonksiyondaki etki mekanizması oksidatif stres, nükleer faktör-kB (NF$\mathrm{kB})$, inflamasyon ve endotel nitrik oksit sentazın inhibisyonunun kombinasyonudur (Baggott ve Tamura, 2015; Ganguly ve Alam, 2015; Martí-Carvajal ve ark., 2015). 


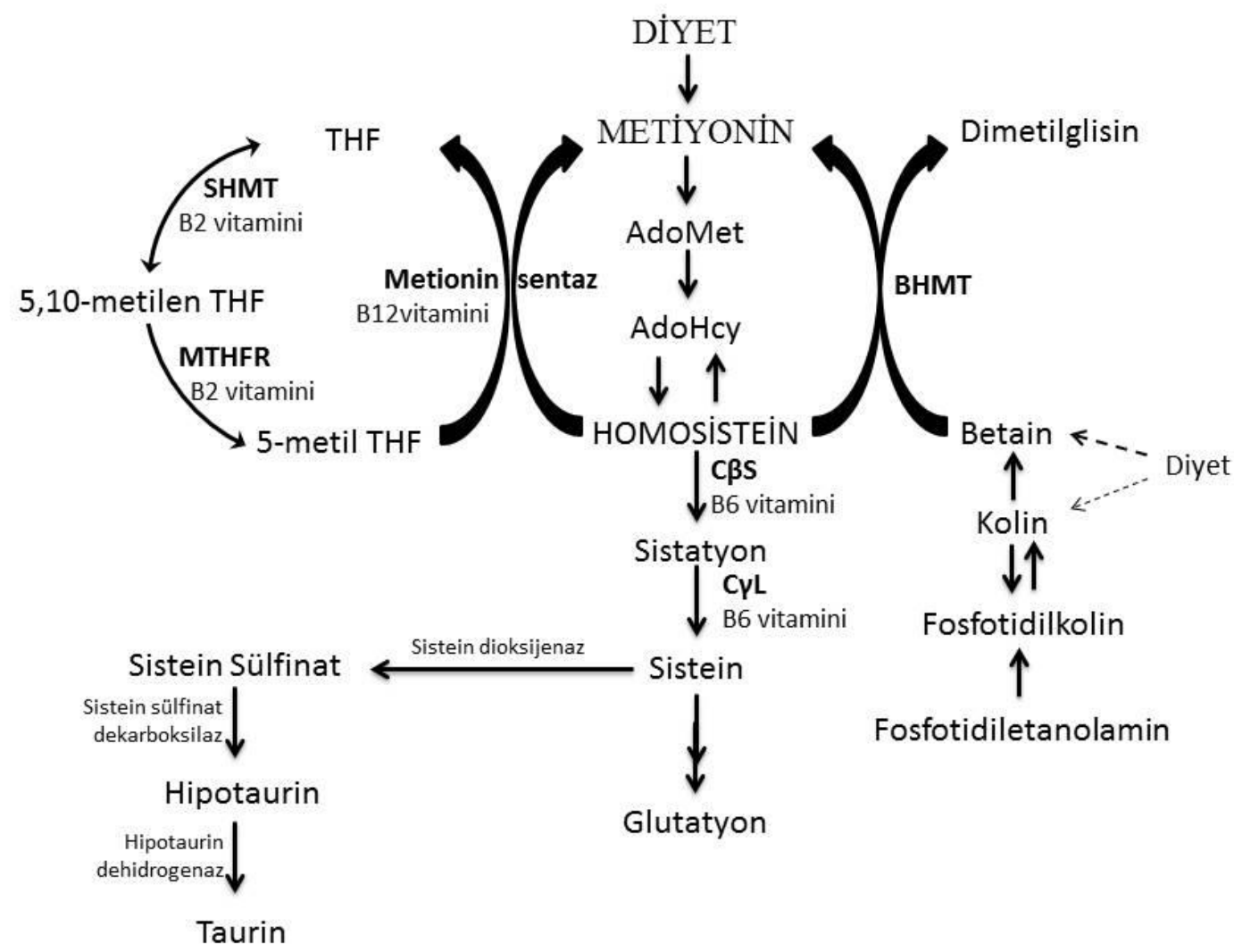

Şekil 1 Kükürtlü aminoasitlerin metabolizması (Poloni ve ark., 2015). AdoHcy, S-adenozilhomosistein; AdoMet, Sadenozilmetiyonin; BHTM, betain homosistein S-metiltransferaz; C $\beta S$, sistatyon $\beta$-sentaz; C $\gamma \mathrm{L}$, sistatyon $\gamma$-liyaz; MTHFR, 5,10-metilen THF redüktaz; SHMT, serin hidroksimetiltransferaz; THF, tetrahidrofolat.

Diğer kükürtlü aminoasit olan taurin özellikle deniz ürünlerinde bol miktarda bulunmakla birlikte (Murakami, 2012; Zulli, 2011) hemen hemen her besinde bulunabilen kükürt içeren aminoasitlerin metabolizmasındaki son üründür (Schaffer ve ark., 2010). Metiyonin ve sistein aminoasidinden endojen sentezlenen taurin miktarı düşüktür. $\mathrm{Bu}$ yüzden temel taurin kaynağı diyettir (Murakami, 2012). Taurinin antiinflamatuar ve antioksidan etkileri bulunmaktadır (Schaffer ve ark., 2014). Endotelde bulunan lökosit, monosit ve platelet gibi inflamatuar hücrelerde taurin aminoasidi bol miktarda bulunmaktadır. Bu yüzden taurin aminoasidi vasküler fonksiyonu düzenleyici etkiye sahiptir denilebilir. Endotel disfonksiyon aterosklerozisin temelinde yatan sebeplerden biri olduğundan taurin ateroskleroz riskini azaltabilmektedir (Murakami, 2012). Ayrıca taurin endotelyal nitrik oksit sentaz enzimini indükleyerek nitrik oksit salınımını ve böylece kan basıncını etkileyebilmektedir (Zulli, 2011).

Taurin alımının DNA, protein ve lipidleri oksidatif hasara karşı koruyarak aterosklerozu etkileyebildiği ve enerji metabolizmasını uyardığı EFSA tarafından rapor edilmiştir (EFSA, 2009). Diğer yandan oral olarak taurin alımının (300 mg/kg/gün) yüksek Fruktoz tüketimine bağlı artan kan total kolesterol, trigliserit ve LDL-K seviyelerini düşürebildiği bazı çalışmalarda yayınlanmıştır (Kirchmair ve ark., 2014; Zulli, 2011). Ayrıca enerji içeceklerinde de yer alan taurinin yüksek doz kafeinin kardiyovasküler sistem üzerine olan yan etkilerini miyokardiyal kas kasılmasını ve kan basıncını regüle ederek azalttığ 1 düşünülmektedir (Schaffer ve ark., 2014).

Başka bir açıdan kükürtlü aminoasitlerin stearoil-CoA desatüraz-1 (SCD-1) enziminin ekspresyonunu modüle ederek yağ asidi ve lipoprotein metabolizmasını etkilediği hipotezi literatürde yer almaktadır. Özetle doymamış yağ asidi sentezinde görev alan SCD-1 enzimi baskılandığında doymamış yağ asil-KoA, trigliserit ve çok düşük yoğunluklu lipoprotein (VLDL) sentezi azalmaktadır. Böylece yağ asit sentezinden sorumlu asetil-KoA karboksilaz enzimi inhibe edilerek yağ asidi oksidasyonunun azaldığı; kan lipid düzeylerinin $\operatorname{arttığ~}_{1}$ ileri sürülmüştür (Poloni ve ark., 2015; Vinknes ve ark., 2013).

\section{Dall Zincirli Aminoasitler}

Dallı zincirli aminoasitler (DZAA) lösin, valin ve izolösin aminoasitlerini içermektedir (Huang ve ark., 2011). Normal büyüme ve gelişme için elzem olmalarına rağmen kandaki yüksek seviyeleri patolojik olabilmektedir (Sun ve ark., 2011). Kanda yüksek DZAA seviyesi insülin direnci, obezite (Batch ve ark., 2013), kardiyovasküler hastalıklar ve kronik böbrek hastalıklarının gelişimi (Huang ve ark., 2011) için risk oluşturabilmektedir. Aynı zamanda kanda DZAA seviyesinin yüksekliği iskemik kalp hastalıkları, tip II diabetes mellitus ve kardiyometabolik hastalıkların mortalite oranını da yükseltebildiği bildirilmiştir (Batch 
ve ark., 2013; Huang ve ark., 2011). Örneğin DZAA'den lösinin çok yüksek miktarda alımının pankreasın $\beta$ hücrelerini uyararak aşırı insülin sekresyonuna ve böylece hiperinsülinemiye neden olarak insülin direnci ve obezite başta olmak üzere kardiyometabolik hastalıklar açısından risk oluşturduğu bildirilmiştir (Newgard, 2012).

Normal fizyolojik koşullarda DZAA diyetle vücuda alındiktan sonra keto asitlere sonrasında ise asetil koenzim-A (KoA) ve süksinil-KoA oluşmakta ve bunlar krebs döngüsüne girerek metabolizmaları tamamlanmaktadır (Sun ve ark., 2011). Kanda DZAA'in ketoasitlere oranının artması yağ asitleri ve pirüvatın hücre içine transportunu ve kullanımını baskılayarak kan lipidlerinin artmasına sebep olacağından kardiyovasküler sağlığ1 olumsuz etkilediği düşünülmektedir (Huang ve ark., 2011; Harald Mangge ve ark., 2016). Diğer yandan DZAA metabolizmasında yer alan keto asit dehidrogenaz enzim kompleksi konjenital kalp hastalıkları ve kalp yetmezliğine de neden olabilmektedir (Huang ve ark., 2011; Sun ve ark., 2011).

Dallı zincirli aminoasitler besin ögesi olma özelliklerinin yanında sinyal iletiminde de görev almaktadırlar. Özellikle de lösin aminoasidi fosfotidilinositol 3- kinaz (PI3K) grubunun bir üyesi olan mTOR (rapamisin protein kompleksinin memeli hedefi) aktivitesini arttırabilmekte (Huang ve ark., 2011) ve hücre büyümesini ve proliferasyonu ile hücrenin hayatta kalması için önemli bir rol oynamaktadır (Liu ve ark., 2009). Bu yolla uyarılan mTOR aktivitesi, kardiyak hipertrofiye neden olabilmektedir (Huang ve ark., 2011). Ayrıca lösin aminoasidinin kandaki konsantrasyonunun normal değerlerin üzerinde olması vazodilatatör etkili nitrik oksit sentezini olumsuz etkileyen bir faktör olduğundan kan basıncının yükselmesine neden olabilir. $\mathrm{Bu}$ yüzden lösin aminoasidinin katabolizmasının düzenlenmesi ve fazla oral destekten kaçınılması endotel fonksiyon açısından önemlidir (Yang ve ark., 2015).

\section{Aromatik Aminoasitler}

Aromatik aminoasitler grubunda triptofan, tirozin ve fenilalanin aminoasitleri bulunmaktadır. Bunlardan fenilalanin ve triptofan aminoasidi elzem iken tirozin aminoasidi böbrekler ve karaciğerde fenilalanin hidroksilaz enzimi ile fenilalaninden sentezlenebilmektedir (Krzyściak, 2011).

Vücuttaki triptofanın yaklaşı \%94'lük kısmı indolamin 2,3-dioksijenaz (IDO) ve triptofan 2,3dioksijenaz enzimleri ile kinurenine (KYN) dönüştürülmektedir (Krzyściak, 2011; H. Mangge ve ark., 2014). Kinurenin ve metabolizması ile oluşan kinurenik asit ve kinolinik asit metabolitlerinin kanda konsantrasyonlarının artması interferon- $\alpha$ (IFN- $\alpha$ ), interferon- $\gamma$ (IFN- $\gamma)$ ve TNF- $\alpha$ gibi proinflamatuar sitokinlerin ve oksidatif stres belirteçlerinin düzeylerini yükselterek ateroskleroz ve endotel disfonksiyon gelişimine neden olabilmektedir. $\mathrm{Bu}$ yüzden IDO enziminin aktivitesinin artması kardiyovasküler hastalık gelişim riski ile ilişkilendirilmektedir (Krzyściak, 2011). Hordaland sağlık çalışmasının populasyonundan seçilen 7501 kişi ile yapılan bir çalışmada kan kinurenin metabolitlerindeki artışın inflamatuar sitokinlerin miktarını arttırdığı gösterilmiştir (Zuo ve ark., 2016).

Triptofandan hipotalamusta sentezlenen melatoninin biyolojik ritm regülatörü, antiinflamatuar, antioksidan, antihipertasif ve az da olsa antihiperlipidemik etkileri olduğu gösterilmiştir. Triptofan metabolizmasındaki herhangi bir bozukluk melatonin sentezini de azaltacağından kardiyovasküler sistem sağlığı için risk oluşturabileceği düşünülebilir (H. Mangge ve ark., 2014). Ratlarda yüksek yağlı diyete ek olarak melatonin (10 $\mathrm{mg} / \mathrm{kg} / \mathrm{gün}$ ) suplemantasyonunun vasküler fonksiyonları geliştirdiği ve oksidatif stresi azalttığ güncel bir çalışmada gösterilmiştir (Selcen Salmanoglu ve ark., 2016).

Tirozin aminoasidinin en iyi bilinen fonksiyonu dopamin sentezinde yer almasidir. Hidroksilaz enzimi aracılığıyla dopamin dihidroksifenilalanine (DOPA) dönüştürülmektedir (Qin ve ark., 2015). Dopamin nörotransmitterinin metabolik öncüsü olan DOPA ve dopamin merkezi sinir sisteminin aktivitesini arttırıp kan renin aktivitesini ve kan basıncını yükseltebilmektedir (Goshima ve ark., 2014).

Tiroid hormonları sentezinde yer alan tirozin aminoasidi kardiyovasküler sistemi tiroid hormonlarına bağlı olarak etkileyebilmektedir (Duntas ve Brenta, 2012; Pingitore ve ark., 2011; van Tienhoven-Wind ve Dullaart, 2015). Tiroid hormonları kardiyak ritimin regülasyonunu sağlamaktadır (Pingitore ve ark., 2011). Aynı zamanda LDL reseptör genini ve düzenleyici etmenlerden biri olan SREBP-2'yi stimüle ederek LDL-K'nın dokulara geçişini sağlayıp klirensini arttırmaktadır (Duntas ve Brenta, 2012; van Tienhoven-Wind ve Dullaart, 2015). Hipotiroidizmde vücut ağırlığı artışına ek olarak dislipidemi, endotel disfonksiyon oluşabilmektedir (van Tienhoven-Wind ve Dullaart, 2015). Hipertiroidizmde ise vücut ağırlığı azalışına ek olarak taşikardi, nabız artışı, bazal metabolizma artışına ilaveten LDL-K ve HDL-K seviyelerinin düştüğü bildirilmiştir (Duntas ve Brenta, 2012). Özetle tirozin varlığında sentezlenen tiroid hormonlarındaki herhangi bir disfonksiyon dislipidemi ve kardiyak ritim bozukluğu başta olmak üzere kardiyovasküler hastalıklar için risk faktördür.

\section{Arjinin, Ornitin ve Sitrulin}

Arjinin yeni doğan ile hastalık ve yaralanma durumunda endojen sentezi yetersiz olabilen bir aminoasit olduğundan koşullara göre esansiyeldir. Arjinin aminoasidinden arjinaz, nitrik oksit sentaz, Larjinin/glisin aminotransferaz ve arjinin karboksilaz enzimleri aracılığıyla (Lorin ve ark., 2014) nitrik oksit, ornitin, üre, poliamin, prolin, glutamat ve kreatinden (Lorin ve ark., 2014; Popolo ve ark., 2014) sentezlenmektedir (Bkz. Şekil 2).

Arjinin endotel nitrik oksit sentezini arttırarak, süperoksit üretimini dolayısıyla vasküler oksidatif hasarı azaltarak, platelet ve lökosit birikimini inhibe ederek ve vasküler düz kas hücre proliferasyonunu arttırarak kardiyovasküler sağlı̆̆ geliştirmektedir (Lubrano ve Balzan, 2015; Popolo ve ark., 2014). Aynı zamanda arjinin; ateroskleroz, koroner arter hastalıklar, miyokard infarktüsü ve periferal vasküler hastalıkların semptomlarını iyileştirmek için klinikte kullanılmaktadır (Heffernan ve ark., 2010). Ancak sistemik inflamasyon veya fizyolojik stresin yüksek olduğu durumlarda arjinin desteği immunonutrisyon açısında tartışmalıdır. 


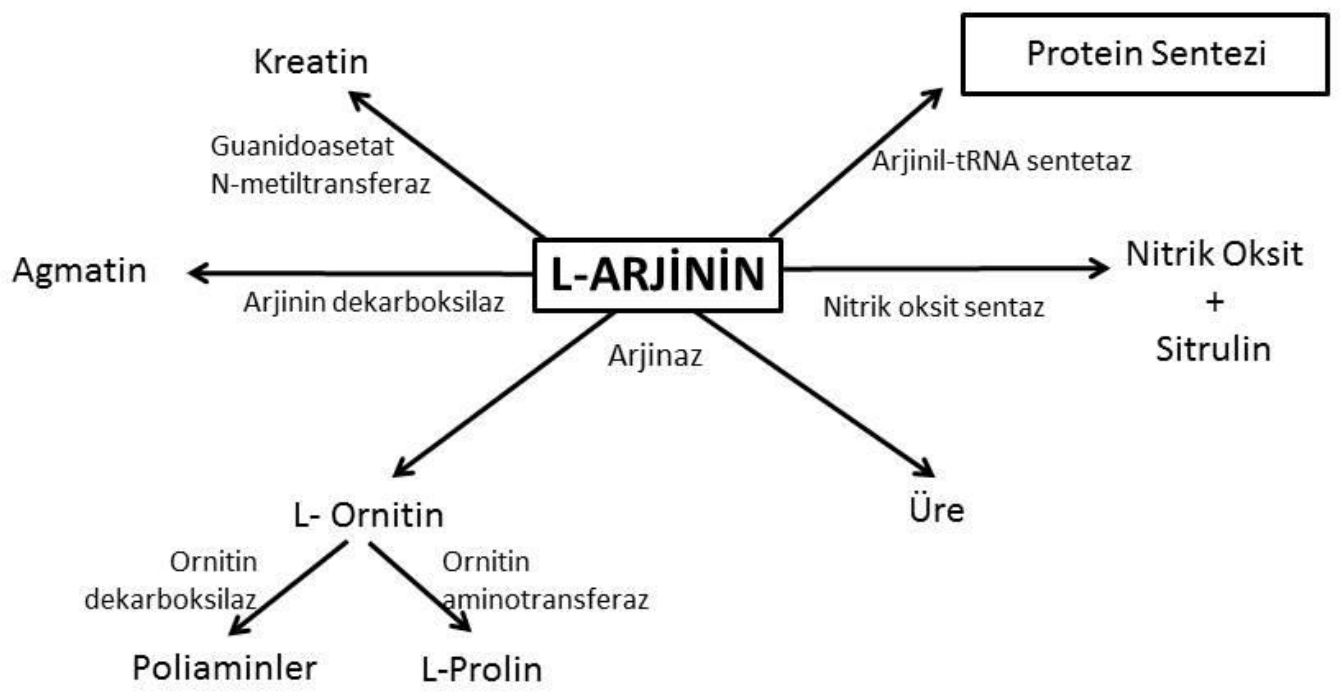

Şekil 2 İnsanlarda arjinin aminoasidinin metabolizması (Popolo ve ark., 2014).

Arjinin; arjinaz ve nitrik oksit sentaz enzimleri için substrattır (Lorin ve ark., 2014; Pernow ve Jung, 2013; Popolo ve ark., 2014; Rabelo ve ark., 2015). Bu iki enzim arjinin katabolizması için yarış halindedirler (Popolo ve ark., 2014). Arjinaz enziminin aktivitesindeki artış kardiyovasküler riski arttırmaktadır (Pernow ve Jung, 2013; Rabelo ve ark., 2015). Çünkü arjininden nitrik oksit sentezinin azalmas1 sonucu kan basincin1, endotel disfonksiyonu ve proinflamasyonu stimule edebilmektedir (Li ve ark., 2014; Pernow ve Jung, 2013; Rabelo ve ark., 2015;Ellis ve ark., 2014).

Arjininin yer aldığı diğer bir metabolik yol da arjinin dekarboksilaz enzimi ile agmatinin sentezlendiği reaksiyondur. Ortamda agmatin konsantrasyonunun normal düzeyde olması endojen nitrik oksit sentezi için regülatör iken; yüksek konsantrasyonları nitrik oksit sentazı inhibe edici etkiye sahip olabilmektedir. Buna ek olarak agmatin; kalp, beyin ve damar fonksiyonları ile hücre proliferasyonunu regüle edebilmektedir (Popolo ve ark., 2014). Ratlarda yapılan bir çalışmada agmatinin nitrik oksit üretimini arttırdığı ve nitrik oksit sentaz enziminin ekspresyonunu indüklediği görülmüştür (Gadkari ve ark., 2013).

Homoarjinin nitrik oksit sentaz için alternatiftir ancak genel olarak zayıf bir substrattır. Nitrik oksit sentezi ile endotel fonksiyonu geliştirdiğinden son yıllarda homoarjininin endotel fonksiyon için bir belirteç olabileceği düşünülmektedir (Atzler ve ark., 2015). Yapılan bir çalışmada kan homoarjinin düzeyinin yükselmesi ile kardiyovasküler hastalık gelişim riski arasında ilişki olduğu gösterilmiştir (Hov ve ark., 2015).
Homoarjinin ile ilgili öneri getirebilmek için yeni çalışmalara ihtiyaç duyulmaktadır.

Arjinin aminoasidi arjinaz enzimi ile ornitine, ornitin de ornitin dekarboksilaz enzimi ile poliaminlere dönüşmektedir (Lin ve ark., 2014; Lorin ve ark., 2014; Newgard, 2012; Popolo ve ark., 2014). Poliamin sentezi için düzenleyici olan ornitin dekarboksilaz enziminin inhibe olması hücre içi poliamin konsantrasyonunu azaltmakta, bu da ornitinin hücre proliferasyonundaki ve programlanmış hücre ölümündeki işlevlerine bağlı hücrelerin hızlı apoptoza girmesine neden olarak kardiyomiyositlerde iskemi nedeni olabilmektedir (Brenner ve ark., 2015; Lin ve ark., 2014; Tantini ve ark., 2006). Hücre içinde ornitin ve poliaminlerin konsantrasyonlarının normal düzeylerde olması özelliklede kardiyak hücrelerin proliferasyonunu regüle ederek kardiyovasküler sağlığı geliştirmektedir (Lin ve ark., 2014). Ancak literatürde kan ornitin seviyesi ile kardiyovasküler hastalık riski arasında ilişkili olmadığını gösteren çalışmalar da vardır (Jazwinska-Kozuba ve ark., 2013).

Arjininden nitrik oksit sentaz enzimi ile sitrulin de sentezlenmektedir (Popolo ve ark., 2014). Sitrulin protein sentezine katılmayan ancak metabolik açıdan önemli olan bir moleküldür (Romero ve ark., 2006). Sitrulin çoğunlukla bağırsaklar tarafından sentezlenmekte ve böbreklerde arjinine tekrar metabolize olmaktadır. Bu özelliği ile de sitrulin arjininin öncüsüdür ve nitrik oksit sentezine katkı sağlamaktadır. Dolaşımda sitrulin seviyesinin yükselmesi nitrik oksit sentezi ile doğrudan ilişkilidir (Bahri ve ark., 2013). Yapılan insan 
çalışmalarında da sitrulin suplemantasyonunun sistolik ve diastolik kan basıncını düşürebildiği gösterilmiştir (Balderas-Munoz ve ark., 2012; Sharif Kashani ve ark., 2014). Ancak diyet açısından değerlendirme ve öneri geliştirmek için bu alanda daha fazla güncel araştırmalara gereksinim duyulmaktadır.

\section{Glutamin}

Metabolik entegrasyonda önemli olan glutamin aminoasidi enterosit ve makrofajlar gibi bağışıklık sistemi hücreleri başta olmak üzere vücutta önemli bir enerji kaynağıdır (van Zanten, 2015). Güncel verilere göre dejeneratif kronik hastalıklar ve fizyolojik stres sonrası glutaminin hücresel düzeyde koruyucu mekanizmalarını uyardığı, inflamatuar yanıtı düzenlediği ve organ hasarının önlenmesinde önemli fonksiyonlara sahip olduğunu göstermektedir. Glutamin, hücre içi sinyal iletiminde ve genlerin ekspresyonununda görev alarak vücutta metabolizmayı düzenlemektedir (Kendler, 2006; Martinez-Gonzalez ve ark., 2016)

Vasküler endotel hücreler ve lipoproteinler peroksidasyona karşı duyarlı oldukları için dejeneratif kardiyovasküler hastalık oluşturma potansiyeline sahiptirler (Polet ve Feron, 2013). Çünkü reaktif oksijen türleri endotelyal nitrik oksit sentaz enzimini etkisizleştirerek endotel disfonksiyona, inflamatuar sitokinlerin sentezini yapan genlerin baskılayarak inflamasyona, biyomoleküllerin peroksidasyonuna neden olarak aterosklerotik plak oluşumuna yol açabilmektedir (Baradaran ve ark., 2014; Li ve ark., 2014). Diğer yandan reaktif oksijen türlerinin etkilerini azaltılmasında glutatyon peroksidaz gibi antioksidan enzimler önemli rol oynamaktadır (Lubrano ve Balzan, 2015). Antioksidan savunma mekanizmalarında yer alan hepatik glutatyon seviyesi de glutamin varlığında korunmaktadır (Malhotra ve Kaufman, 2007; Roman ve ark., 2014; Rose ve Hoffmann, 2014; Zeeshan ve ark., 2016).

\section{Diğer Aminli Bileşikler ve Etkileri}

\section{Trimetilamin $N$-oksit}

Trimetilamin N-oksit (TMAO) deniz ürünlerinden diyet ile alınabilir veya vücutta sentezlenebilir (Ierardi ve ark., 2015; Wilson ve ark., 2016). Trimetilamin N-oksit sentezinde kullanılan kolin ve fosfotidil kolin kırmızı et, yumurta, soya fasulyesi ve yer fistığında; karnitin ise kırmızı et, süt ürünleri, yer fistığ 1 ve kuşkonmazda bulunmaktadır (Drosos ve ark., 2015). Aynı zamanda karnitin endojen olarak bitki ve hayvan proteinlerinde bulunan lizin aminoasidinden de sentezlenmektedir (W. H. Wilson Tang ve Hazen, 2014).

Bağırsak mikrobiyotası ve karaciğerde kolin, fosfotidil kolin ve karnitinden kardiyovasküler sistem için risk oluşturan TMAO sentezlemektedir (Ierardi ve ark., 2015; Richter ve ark., 2015; Wilson ve ark., 2016). Bağırsağın bakteriyel kompozisyonu TMAO sentezini etkilediği için bağırsak mikroflorasının sağlığı ve devamlılığı kardiyovasküler sağlık için elzemdir (Drosos ve ark., 2015). Fosfotidil kolin, kolin ve karnitin başlangıçta bağırsak mikrobiyotasının özellikle de Firmicutes Phylum bakterilerinin aktivitesi sonucu trimetilamin liyaz enzimi ile trimetilamine dönüşür (Richter ve ark., 2015; Wilson ve ark., 2016). Daha sonra trimetilamin karaciğerde flavin monooksijenaz (FMO) özellikle de FMO3 izomeri enzim aracılığı ile TMAO'ya dönüştürülerek dolaşıma salınır (Ierardi ve ark., 2015; Richter ve ark., 2015; Wilson ve ark., 2016).

Kandaki TMAO seviyesinin yükselmesi aterosklerotik plak gelişimini hızlandırmakta, HDL-K aracılı ters kolesterol metabolizmasını azaltmakta, safra asitlerinin miktar ve içeriğini değiştirmekte ve böylece kolesterol metabolizmasını etkileyerek kardiyovasküler sağlığı olumsuz etkilemektedir (Richter ve ark., 2015; Wilson Tang ve Hazen, 2014). Aynı zamanda TMAO proaterojenik reseptör olan CD-36'nın ekspresyonunu arttırarak ateroskleroz gelişiminde rol oynayabilmektedir (Ierardi ve ark., 2015; Nergiz-Unal ve ark., 2011). Trimetilamin N-oksitin atım yolu böbrekler olup böbrek fonksiyonları bozukluklarında TMAO birikimi kardiyovasküler sistem için daha ciddi bir risk faktörü olmaktadır (Wilson Tang ve Hazen., 2014). Yapılan çalışmaların sonucunda kan TMAO konsantrasyonun yükselmesi ateroskleroz gelişim riskini (Stubbs ve ark., 2015), koroner arter hastalıklar ve miyokard infarktüsü riskini (Wang ve ark., 2011), tromboz riskini (Zhu ve ark., 2016) arttırdığı ve inflamatuar gen ekspresyonunu tetiklediği (Seldin ve ark., 2016) görülmüştür.

\section{Heterosiklik Aromatik Aminler}

Heterosiklik aromatik aminler (HAA) sıcaklığın etkisi ile nitrojen içeren özellikle protein içeriği yüksek et gibi besinlerde oluşmaktadırlar. Bugüne kadar 25'den fazla mutajenik/karsinojenik HAA pişmiş besinlerden izole edilmiştir (Alaejos ve ark., 2008; Murkovic, 2007) Oluşumları için gerekli 1sı aralıkları farklılığına bağlı olarak temelde iki gruba ayrilır. $100-300^{\circ} \mathrm{C}$ arasında oluşanlar termik veya polar tip HAA olarak tanımlanırken, $\quad 300^{\circ} \mathrm{C}$ 'nin üzerindeki sıcaklıklarda oluşanlar pirolitik veya polar olmayan tip HAA olarak adlandırılır (Alaejos ve ark., 2008; Murkovic, 2007).

Diyetle alınan HAA vücutta aktif formlara dönüşerek kardiyovasküler sistemi etkileyebilmektedir. Heterosiklik aminler vücuda alındıktan sonra metabolik olarak sitotoksik ve mutajenik olan daha aktif ara metabolitlere/bileşiklere dönüşmektedir (Murphy ve ark. 2001). Diyetle alınan HAA'nın genelde sitokrom faz I enzimler tarafindan katalizlenerek biyolojik olarak aktif metabolitlerine dönüştüğü düşünülmektedir (Alaejos ve ark., 2008). Bu metabolitlerin DNA ile direkt reaksiyona girerek veya faz II enzimleri ile oluşan daha aktif metabolitlere dönüşerek genotoksisite oluşturabileceği bildirilmiş̧tir (Alaejos ve ark., 2008; Lopez-Mendez ve ark., 2009).

Pirolitik HAA oluşumunda piroliz işlemi ile oluşan aktif metabolitler proteinlerin, lipidlerin ve nükleik asitlerin hasarına sebep olarak kardiyovasküler hastalıklar için risk etmeni oluşturmaktadır. Bir çalışmada kişilerin tükettikleri HAA miktarı ile oksidatif stres arasında doğrusal ilişki olduğu görülmüştür (Carvalho ve ark., 2015). Bu biyokimyasal mekanizmalardan dolayı HAA insanlar için kardiyovasküler risk etmeni olarak görülmektedir.

\section{Polisiklik Aromatik Hidrokarbonlar}

Polisiklik aromatik hidrokarbonlar (PAH) yüksek sıcaklığa maruz kalmış etlerde yüksek konsantrasyonlarda 
bulunabilmektedir (Ferguson, 2010; Ramos ve Moorthy, 2008). Besinlerde 1zgara yapma veya kavurma gibi 1sil işlemlerle pişirme sürecinde PAH'lar oluşmaktadır. Oluşumlarını besin hazırlama işlemleri, pişirme de kullanılan kömür, odun gibi yakıtlar, pişirme yöntemleri, pişirme sıcaklığı ve süresi, besinin yağ içeriği, besinin 1 sı ile direkt temas edip etmediği gibi birçok faktör etkilemektedir (Oz ve Yuzer, 2016).

Polisiklik aromatik hidrokarbonlar inaktif bileşiklerdir, aktivite gösterebilmeleri için sitokrom P450 enzim sistemi ile metabolize olmaları gerekir. $\mathrm{Bu}$ sitokrom enzimlerinden CYP1A enzimi ve CYP1A1 alt grubu PAH'ların metabolik aktivasyonuna neden olarak başta kanser olmak üzere ateroskleroz ve diğer bazı metabolik hastalıkların riskini arttırmaktadır. Genotoksik etkiye sahip PAH'lara bağlı DNA hasarı insanlarda aterosklerotik plak lezyonlarına neden olabilmektedir (Ramos ve Moorthy, 2008). Güncel bir çalışmada insanlarda PAH'lara maruziyetin artması ile kardiyovasküler hastalık riski arasında doğrusal ilişki olduğu gösterilmiştir (Alshaarawy ve ark., 2016).

\section{Maillard Reaksiyonu Ürünleri}

Maillard reaksiyonu karbonhidratların serbest karbonil grupları ile proteinlerin veya aminoasitlerin serbest amino grupları arasında gerçekleşmektedir ve besinin besin ögesi kalitesini düşürmektedir (Tessier ve Birlouez-Aragon, 2010). Maillard reaksiyonlarında karbonhidrat ve aminoasitler yüksek ısının etkisi ile yoğunlaştıktan sonra dehidrasyon ile hidroksimetilfurfural ve pürivaldehit gibi bileşikler oluşmaktadır. Reaksiyonların sonunda kahverengileşme ve farklı tattan sorumlu bileşikler olan melanoidinler oluşmaktadır (Tamanna ve Mahmood, 2015).

Melanoidinlerin oksidatif stres ve inflamasyonu arttırdığı için kronik hastalıklar açısından risk oluşturabileceği gösterilmiştir (Tamanna ve Mahmood, 2015). Yüksek doz melonoid alımı hidroksil radikallerinin oluşumunu indükleyeceği için prooksidan etki de göstermektedir (Carvalho ve ark., 2014). Diyetle alınan Maillard reaksiyonu ürünleri TNF- $\alpha$, IL-6 gibi inflamatuar sitokinlerin artmasına, nitrik oksit sentazın ekspresyonunun azalmasına ve serbest radikallerin üretiminin artmasına neden olabildiği ve kardiyovasküler sağlığı bozabilmekte olduğu bazı çalışmalarda yayınlanmıştır (Kellow ve Coughlan, 2015; Tessier ve Birlouez-Aragon, 2010).

Farklı pişirme 1sıları ile hazırlanan besinlerin tüketiminin sağlık üzerine etkisinin araştırıldığı bir çalışmanın sonucunda yüksek ısıda pişen besinleri tüketen grupta kan kolesterol ve trigliserit düzeylerinin arttığ gösterilmiştir (Birlouez-Aragon ve ark., 2010). Diğer bir çalışmada yüksek 1sıda pişirme sonucu diyetle Maillard reaksiyonu ürünlerinin alımının kan IL-6, TNF- $\alpha$ ve CRP gibi inflamatuar sitokinlerin düzeylerini etkilemediği gösterilmiştir (Semba ve ark., 2014). Bu tür aminlerin kardiyovasküler sistem üzerine etkisi ile ilgili çalışmalar çelişkili olup daha fazla kontrollü çalışmaya ihtiyaç vardır.

\section{Kaynaklar}

Alaejos MS, González V, Afonso A. 2008. Exposure to heterocyclic aromatic amines from the consumption of cooked red meat and its effect on human cancer risk: A review. Food Additives \& Contaminant., 25(1): 2-24. doi:10.1080/02652030701474235

Alshaarawy O, Elbaz HA, Andrew ME. 2016. The association of urinary polycyclic aromatic hydrocarbon biomarkers and cardiovascular disease in the US population. Environment International., 89-90: 174-178. doi:10.1016/ j.envint.2016.02.006

Andersen CJ. 2015. Bioactive egg components and inflammation. Nutrients., 7(9): 7889-7913. doi:10.3390/ nu7095372

Astrup A. 2014. Yogurt and dairy product consumption to prevent cardiometabolic diseases: epidemiologic and experimental studies. Am J Clin Nutr., 99(5 Suppl): 1235S1242S. doi:10.3945/ajcn.113.073015

Atzler D, Schwedhelm E, Choe C.-u. 2015. L-Homoarginine and cardiovascular disease. Current Opinion in Clinical Nutrition and Metabolic Care., 18(1): 83-88. doi:10.1097/mco.0000000000000123

Baggott J, Tamura T. 2015. Homocysteine, iron and cardiovascular disease: A hypothesis. Nutrients., 7(2): 11081118. doi:10.3390/nu7021108

Bahri S, Zerrouk N, Aussel C, Moinard C, Crenn P, Curis E, Chaumeil JC, Cynober L, Sfar S. 2013. Citrulline: from metabolism to therapeutic use. Nutrition., 29(3): 479-484. doi:10.1016/j.nut.2012.07.002

Balderas-Munoz K, Castillo-Martínez L, Orea-Tejeda A, Infante-Vázquez O, Utrera-Lagunas M, Martínez-Memije R, Keirns-Davis C, Becerra-Luna B, Sánchez-Vidal G. 2012. Improvement of ventricular function in systolic heart failure patients with oral L-citrulline supplementation. Cardiology Journal., 9(6): 612-617.

Baradaran A, Nasri H, Rafieian-Kopaei M. 2014. Oxidative stress and hypertension: Possibility of hypertension therapy with antioxidants. J Res Med Sci., 19: 358-367.

Batch BC, Hyland K, Svetkey LP. 2013. Branch chain amino acids. Current Opinion in Clinical Nutrition and Metabolic Care., 17(1): 86-89. doi:10.1097/mco.0000000000000010

Bhupathiraju SN, Tucker KL. 2011. Coronary heart disease prevention: nutrients, foods, and dietary patterns. Clin Chim Acta., $\quad 412(17-18)$ : 1493-1514. doi:10.1016/j.cca.2011.04.038

Birlouez-Aragon I, Saavedra G, Tessier FJ, Galinier A, AitAmeur L, Lacoste F, Niamba CN, Alt N, Somoza V, Lecerf JM. 2010. A diet based on high-heat-treated foods promotes risk factors for diabetes mellitus and cardiovascular diseases. American Journal of Clinical Nutrition., 91(5): 1220-1226. doi:10.3945/ajcn.2009.28737.

Brenner S, Bercovich Z, Feiler Y, Keshet R, Kahana C. 2015. Dual regulatory role of polyamines in adipogenesis. Journal of Biological Chemistry., 290(45): 27384-27392. doi:10.1074/jbc.M115.686980

Carvalho AM, Miranda AM, Santos FA, Loureiro APM, Fisberg RM, Marchioni DM. 2015. High intake of heterocyclic amines from meat is associated with oxidative stress. British Journal of Nutrition., 113(08): 1301-1307. doi:10.1017/s0007114515000628

Carvalho DO, Correia E, Lopes L, Guido LF. 2014. Further insights into the role of melanoidins on the antioxidant potential of barley malt. Food Chemistry., 160: 127-133. doi:10.1016/j.foodchem.2014.03.074.

Cavazos A, Gonzalez de Mejia E. 2013. Identification of bioactive peptides from cereal storage proteins and their potential role in prevention of chronic diseases. Comprehensive Reviews in Food Science and Food Safety., 12(4): 364-380. doi:10.1111/1541-4337.12017. 
Chakrabarti S, Jahandideh F, Wu J. 2014. Food-derived bioactive peptides on inflammation and oxidative stress. BioMed Research International., 2014: 1-11. doi:10.1155/2014/608979.

Clifton PM, Bastiaans K, Keogh JB. 2009. High protein diets decrease total and abdominal fat and improve CVD risk profile in overweight and obese men and women with elevated triacylglycerol. Nutr Metab Cardiovasc Dis., 19(8): 548-554. doi:10.1016/j.numecd.2008.10.006.

Dahl WJ, Foster LM, Tyler RT. 2012. Review of the health benefits of peas (Pisum sativum L.). British Journal of Nutrition., $\quad$ 108(S1): $\quad$ S3-S10. doi:10.1017/ s0007114512000852.

de Luis DA, Aller R, Izaola O, Primo D, Urdiales S, Romero E. 2015. Effects of a high-protein/low-carbohydrate diet versus a standard hypocaloric diet on weight and cardiovascular risk factors: role of a genetic variation in the rs9939609 FTO gene variant. Journal of Nutrigenetics and Nutrigenomics., 8(3): 128-136. doi:10.1159/000441142.

Drosos I, Tavridou A, Kolios G. 2015. New aspects on the metabolic role of intestinal microbiota in the development of atherosclerosis. Metabolism., 64(4): 476-481. doi:10.1016/j.metabol.2015.01.007.

Duntas LH, Brenta G. 2012. The effect of thyroid disorders on lipid levels and metabolism. Medical Clinics of North America., 96(2): 269-281. doi:10.1016/j.mcna.2012.01.012.

EFSA. 2009. European Food Safety Authority. Scientific Opinion on the substantiation of health claims related to taurine and protection of DNA, proteins and lipids from oxidative damage (ID 612, 1658, 1959), energy-yielding metabolism (ID 614), and delay in the onset of fatigue and enhancement of physical performance (ID 1660). EFSA Journal., 7(9): 1260. doi:10.2903/j.efsa.2009.1260.

EFSA. 2010a. European Food Safety Authority. Scientific Opinion on the substantiation of health claims related to bonito protein peptide and maintenance of normal blood pressure. EFSA Journal., 8(10): 1730. doi:10.2903/ j.efsa.2010.1730.

EFSA. 2010b. European Food Safety Authority. Scientific Opinion on the substantiation of a health claim related to soy protein and reduction of blood cholesterol concentrations. EFSA Journal., 8(7): 1688. doi:10.2903/j.efsa.2010.1688.

El Khoury D, Anderson GH. 2013. Recent advances in dietary proteins and lipid metabolism. Curr Opin Lipidol., 24(3): 207-213. doi:10.1097/MOL.0b013e3283613bb7.

Ellis A, Patterson M, Dudenbostel T, Calhoun D, Gower B. 2014. Effects of 6-month supplementation with $\beta$-hydroxy$\beta$ - methylbutyrate, glutamine and arginine on vascular endothelial function of older adults. European Journal of Clinical Nutrition., 70: 269-273. doi:10.1038/ejen.2015.137

FDA. 2013. Food and Drug Administration. A food labeling guide: guidance for industry. http://www.fda.gov/ Food/GuidanceRegulation/GuidanceDocumentsRegulatoryI nformation/LabelingNutrition/ucm064866.htm, (erişim tarihi: 20.06.2016)

Ferguson LR. 2010. Meat and cancer. Meat Science., 84(2): 308-313. doi:10.1016/j.meatsci.2009.06.032.

Gadkari T, Cortes N, Madrasi K, Tsoukias N, Joshi M. 2013. Agmatine induced NO dependent rat mesenteric artery relaxation and its impairment in salt-sensitive hypertension. Nitric Oxide., 35: 65-71. doi:10.1016/j.niox.2013.08.005.

Ganguly P, Alam S. 2015. Role of homocysteine in the development of cardiovascular disease. Nutrition Journal., 14: 6.

García MC, Puchalska P, Esteve C, Marina ML. 2013. Vegetable foods: A cheap source of proteins and peptides with antihypertensive, antioxidant, and other less occurrence bioactivities. Talanta., 106: 328-349. doi:10.1016 /j.talanta.2012.12.041.
Glier MB, Green TJ, Devlin AM. 2014. Methyl nutrients, DNA methylation, and cardiovascular disease. Molecular Nutrition \& Food Research., 58(1): 172-182. doi:10.1002/mnfr.201200636.

Goshima Y, Nakamura F, Masukawa D, Chen S, Koga M. 2014. The cardiovascular actions of DOPA mediated by the gene product of ocular albinism 1. Journal of Pharmacological Sciences., 126(1): 14-20. doi:10.1254/jphs.14R03CR.

Heffernan KS, Fahs CA, Ranadive SM., Patvardhan EA. 2010. Review Article: L-Arginine as a nutritional prophylaxis against vascular endothelial dysfunction with aging. Journal of Cardiovascular Pharmacology and Therapeutics., 15(1): 17-23. doi:10.1177/1074248409354599.

Hov G, Aasarød K, Sagen E, Åsberg A. 2015. Arginine, dimethylated arginine and homoarginine in relation to cardiovascular risk in patients with moderate chronic kidney disease. Clinical Biochemistry., 48: 646-651. doi:10.1016/j.clinbiochem.2015.03.012.

Huang Y, Zhou M, Sun H, Wang Y. 2011. Branched-chain amino acid metabolism in heart disease: an epiphenomenon or a real culprit? Cardiovascular Research., 90(2): 220-223. doi: $10.1093 / \mathrm{cvr} / \mathrm{cvr} 070$.

Ierardi E, Sorrentino C, Principi M, Giorgio F, Losurdo G, Di Leo A. 2015. Intestinal microbial metabolism of phosphatidylcholine: a novel insight in the cardiovascular risk scenario. HepatoBiliary Surg Nutr., 4(4): 289-292. doi:10.3978/j.issn.2304-3881.2015.02.01.

Jahan-Mihan A, Luhovy BL, El Khoury D, Anderson GH. 2011. Dietary proteins as determinants of metabolic and physiologic functions of the gastrointestinal tract. Nutrients., 3(5): 574-603. doi:10.3390/nu3050574.

Jazwinska-Kozuba A, Martens-Lobenhoffer J, Kruszelnicka O, Rycaj J, Chyrchel B, Surdacki A, Bode-Boger SM. 2013. Opposite associations of plasma homoarginine and ornithine with arginine in healthy children and adolescents. Int $\mathrm{J}$ Mol Sci., 14(11): 21819-21832. doi:10.3390/ijms141121819.

Kellow NJ, Coughlan MT. 2015. Effect of diet-derived advanced glycation end products on inflammation. Nutrition Reviews., 73(11): 737-759. doi:10.1093/nutrit/nuv030.

Kendler BS. (2006). Supplemental conditionally essential nutrients in cardiovascular disease therapy. Journal of Cardiovascular Nursing., 21(1), 9-16.

Kirchmair R, Maia AR, Batista TM, Victorio JA, Clerici SP, Delbin MA, Carneiro EM, Davel AP. 2014. Taurine supplementation reduces blood pressure and prevents endothelial dysfunction and oxidative stress in post-weaning protein-restricted rats. Plos One., 9(8): e105851. doi:10.1371/journal.pone.0105851.

Kouguchi T, Ohmori T, Shimizu M, Takahata Y, Maeyama Y, Suzuki T, Morimatsu F, Tanabe S. 2014. Effects of a chicken collagen hydrolysate on the circulation system in subjects with mild hypertension or high-normal blood pressure. Bioscience, Biotechnology and Biochemistry., 77(4): 691-696. doi:10.1271/bbb.120718.

Koury OH, Scheede-Bergdahl C, Bergdahl A. 2014. The role of casein in the development of hypercholesterolemia. J Physiol Biochem., 70(4): 1021-1028. doi:10.1007/s13105014-0365-9.

Krzyściak W. 2011. Activity of selected aromatic amino acids in biological systems. Acta Biochimica Polonica., 58(4): 461466.

Lafarga T, Hayes M. 2014. Bioactive peptides from meat muscle and by-products: generation, functionality and application as functional ingredients. Meat Science., 98(2): 227-239. doi:10.1016/j.meatsci.2014.05.036.

Li H, Horke S, Förstermann U. 2014. Vascular oxidative stress, nitric oxide and atherosclerosis. Atherosclerosis., 237(1): 208-219. doi:10.1016/j.atherosclerosis.2014.09.001. 
Lin Y, Zhang X, Wang L, Zhao Y, Li H, Xiao W, Xu C, Liu J. 2014. Polyamine depletion attenuates isoproterenol-induced hypertrophy and endoplasmic reticulum stress in cardiomyocytes. Cellular Physiology and Biochemistry., 34(5): 1455-1465. doi:10.1159/000366350.

Liu J, Jia SH, Kirberger M, Chen N. 2014. Lunasin as a promising health-beneficial peptide. European Review for Medical and Pharmacological Sciences., 18: 2070-2075.

Liu P, Cheng H, Roberts TM, Zhao JJ. 2009. Targeting the phosphoinositide 3-kinase pathway in cancer. Nature Reviews Drug Discovery., 8(8): 627-644. doi:10.1038/nrd2926.

Lopez-Mendez C, Bermudez-Fajardo A, Ioannides C, OviedoOrta E. 2009. Effect of 2-amino-9H-pyrido[2,3-b]indole $(\mathrm{A} \alpha \mathrm{C})$, a carcinogenic heterocyclic amine present in food, on atherosclerotic plaque development in apoE deficient mice. Toxicology Letters., 185(2): 73-78. doi:10.1016/j.toxlet.2008.11.014.

Lorin J, Zeller M, Guilland JC, Cottin Y, Vergely C, Rochette L. 2014. Arginine and nitric oxide synthase: Regulatory mechanisms and cardiovascular aspects. Molecular Nutrition \& Food Research., 58(1): 101-116. doi:10.1002/ mnfr.201300033.

Lubrano V, Balzan S. 2015. Enzymatic antioxidant system in vascular inflammation and coronary artery disease. World Journal of Experimental Medicine., 5(4): 218-224. doi: $10.5493 /$.

Lule VK, Garg S, Pophaly SD, Hitesh SK. 2015. Potential health benefits of lunasin: A multifaceted soy-derived bioactive peptide. Journal of Food Science., 80(3): R485R494. doi:10.1111/1750-3841.12786.

Majumder K, Liang G, Chen Y, Guan L, Davidge ST, Wu J. 2015. Egg ovotransferrin-derived ACE inhibitory peptide IRW increases ACE2 but decreases proinflammatory genes expression in mesenteric artery of spontaneously hypertensive rats. Molecular Nutrition \& Food Research., 59(9): 1735-1744. doi:10.1002/mnfr.201500050.

Malaguti M, Dinelli G, Leoncini E, Bregola V, Bosi S, Cicero A, Hrelia S. 2014. Bioactive peptides in cereals and legumes: agronomical, biochemical and clinical aspects. International Journal of Molecular Sciences., 15(11): 2112021135. doi:10.3390/ijms 151121120 .

Malhotra JD, Kaufman RJ. 2007. Endoplasmic reticulum stress and oxidative stress: A vicious cycle or a double-edged sword? Antioxidants \& Redox Signaling., 9(12): 2277-2294. doi:10.1089/ars.2007.1782.

Mangge H, Stelzer I, Reininghaus E, Weghuber D, Postolache T, Fuchs D. 2014. Disturbed tryptophan metabolism in cardiovascular disease. Current Medicinal Chemistry., 21(1).

Mangge H, Zelzer S, Prüller F, Schnedl WJ, Weghuber D, Enko D, Bergsten P, Haybaeck J, Meinitzer A. 2016. Branchedchain amino acids are associated with cardiometabolic risk profiles found already in lean, overweight and obese young. The Journal of Nutritional Biochemistry., 32: 123-127. doi:10.1016/j.jnutbio.2016.02.007.

Martí-Carvajal A, Solà I, Lathyris D. 2015. Homocysteinelowering interventions for preventing cardiovascular events. The Cochrane Collaboration., http://www. thecochranelibrary.com. (erişim tarihi: 27.07.2016)

Martinez-Gonzalez MA, Ruiz-Canela M, Hruby A, Liang L, Trichopoulou A, Hu FB. 2016. Intervention trials with the mediterranean diet in cardiovascular prevention: Understanding potential mechanisms through metabolomic profiling. J Nutr., doi:10.3945/jn.115.219147.

Miguel M, Aleixandre A. 2006. Antihypertensive peptides derived from egg proteins. Journal of Nutrition., 136: 1457 1460.

Murakami, S. 2012. Taurine and atherosclerosis. Amino Acids., 46(1): 73-80. doi:10.1007/s00726-012-1432-6.
Murkovic M. 2007. Analysis of heterocyclic aromatic amines. Anal Bioanal Chem., 389: 139-146.

Murphy DB, Behiery HE, Chan VW, \& JF, F. (2001). Pharmacokinetic profile of epidurally administered methylnaltrexone, a novel peripheral opioid antagonist in a rabbit model. British Journal of Anaesthesia., 86(1): 120122.

Nergiz-Unal R, Lamers MM, Van Kruchten R, Luiken JJ, Cosemans JM, Glatz JF, Kuijpers MJ, Heemskerk JW. 2011. Signaling role of CD36 in platelet activation and thrombus formation on immobilized thrombospondin or oxidized lowdensity lipoprotein. J Thromb Haemost., 9(9): 1835-1846. doi:10.1111/j.1538-7836.2011.04416.x.

Newgard Christopher B. 2012. Interplay between lipids and branched-chain amino acids in development of insulin resistance. Cell Metabolism., 15(5): 606-614. doi:10.1016/j.cmet.2012.01.024.

Oz F, Yuzer MO. 2016. The effects of cooking on wire and stone barbecue at different cooking levels on the formation of heterocyclic aromatic amines and polycyclic aromatic hydrocarbons in beef steak. Food Chemistry., 203: 59-66. doi:10.1016/j.foodchem.2016.02.041.

Pal, S, Radavelli-Bagatini S. 2013. The effects of whey protein on cardiometabolic risk factors. Obes Rev., 14(4): 324-343. doi:10.1111/obr.12005.

Patil P, Mandal S, Tomar SK, Anand S. 2015. Food proteinderived bioactive peptides in management of type 2 diabetes. Eur J Nutr., 54(6): 863-880. doi:10.1007/s00394015-0974-2.

Perk J, De Backer G, Gohlke H, Graham I, Reiner Z, Verschuren M, Albus C, Benlian P, Boysen G, Cifkova R, Deaton C, Ebrahim S, Fisher M, Germano G, Hobbs R, Hoes A, Karadeniz S, Mezzani A, Prescott E, Ryden L, Scherer M, Syvanne M, Scholte op Reimer WJ, Vrints C, Wood D, Zamorano JL, Zannad F. 2012. European Guidelines on cardiovascular disease prevention in clinical practice (version 2012). The fifth joint task force of the european society of cardiology and other societies on cardiovascular disease prevention in clinical practice (constituted by representatives of nine societies and by invited experts). Eur Heart J., 33(13): 1635-1701. doi:10.1093/eurheartj/ehs092.

Pernow J, Jung C. 2013. Arginase as a potential target in the treatment of cardiovascular disease: reversal of arginine steal? Cardiovascular Research., 98(3): 334-343. doi:10.1093/cvr/cvt036.

Pingitore A, Chen Y, Gerdes AM, Iervasi G. 2011. Acute myocardial infarction and thyroid function: New pathophysiological and therapeutic perspectives. Annals of Medicine., 44(8): 745-757. doi:10.3109/ 07853890.2011.573501.

Polet F, Feron O. 2013. Endothelial cell metabolism and tumour angiogenesis: glucose and glutamine as essential fuels and lactate as the driving force. Journal of Internal Medicine., 273(2): 156-165. doi:10.1111/joim. 12016.

Poloni S, Blom H, Schwartz I. 2015. Stearoyl-CoA desaturase1: Is it the link between sulfur amino acids and lipid metabolism? Biology., 4(2): 383-396. doi:10.3390/ biology 4020383 .

Popolo A, Adesso S, Pinto A, Autore G, Marzocco S. 2014. LArginine and its metabolites in kidney and cardiovascular disease. Amino Acids., 46(10): 2271-2286. doi:10.1007/ s00726-014-1825-9.

Qin XF, Zhao LS, Chen WR, Yin da W, Wang H. 2015. Effects of vitamin D on plasma lipid profiles in statin-treated patients with hypercholesterolemia: A randomized placebocontrolled trial. Clin Nutr., 34(2): 201-206. doi:10.1016/j.clnu.2014.04.017. 
Rabelo LA, Ferreira FO, Nunes-Souza V, Fonseca LJS, Goulart MOF. 2015. Arginase as a critical prooxidant mediator in the binomial endothelial dysfunction-atherosclerosis. Oxidative Medicine and Cellular Longevity., 2015: 1-12. doi:10.1155/2015/9248.

Ramos KS, Moorthy B. 2008. Bioactivation of polycyclic aromatic hydrocarbon carcinogens within the vascular wall: Implications for human atherogenesis. Drug Metabolism Reviews., $\quad 37(4)$ : $\quad 595-610 . \quad$ doi:10.1080 $/ 03602530500251253$.

Rice BH, Cifelli CJ, Pikosky MA, Miller GD. 2011. Dairy components and risk factors for cardiometabolic syndrome: recent evidence and opportunities for future research. Adv Nutr., 2(5): 396-407. doi:10.3945/an.111.000646.

Richter CK, Skulas-Ray AC, Champagne CM, Kris-Etherton PM. 2015. Plant protein and animal proteins: do they differentially affect cardiovascular disease risk? Adv Nutr., 6(6): 712-728. doi:10.3945/an.115.009654.

Roman M, Jitaru P, Barbante C. 2014. Selenium biochemistry and its role for human health. Metallomics., 6(1): 25-54. doi:10.1039/c3mt00185g.

Romero M, Platt D, Caldwell R, Caldwell W. 2006. Therapeutic use of citrulline in cardiovascular disease. Cardiovascular Drug Reviews., 24(3-4): 275-290.

Rose AH, Hoffmann PR. 2014. Selenoproteins and cardiovascular stress. Thrombosis and Haemostasis., 113(3): 494-504. doi:10.1160/th14-07-0603.

Ruiz Ruiz J, Betancur Ancona D, Segura Campos M. 2014. Bioactive vegetable proteins and peptides in lipid-lowering; nutraceutical potential. Nutr Hosp., 29: 776-784 doi:10.3305/nh.2014.29.4.7208.

Ryan JT, Ross RP, Bolton D, Fitzgerald GF, Stanton C. 2011. Bioactive peptides from muscle sources: meat and fish. Nutrients., 3(9): 765-791. doi:10.3390/nu3090765.

Sacks FM, Lichtenstein A, Van Horn L, Harris W, Kris-Etherton P, Winston M. 2006. Soy protein, isoflavones, and cardiovascular health: An American Heart Association Science Advisory for Professionals From the Nutrition Committee. Circulation., 113(7): 1034-1044. doi:10.1161/circulationaha.106.171052.

Saita KK, Momiyama Y. 2015. Anti-Inflammatory diet for atherosclerosis and coronary artery disease: Antioxidant foods. Clinical Medicine Insights: Cardiology., 8: 61. doi:10.4137/cmc.s17071.

Salehi-Abargouei A, Maghsoudi Z, Shirani F, Azadbakht L. 2013. Effects of dietary approaches to stop hypertension (DASH)-style diet on fatal or nonfatal cardiovascular diseases--incidence: a systematic review and meta-analysis on observational prospective studies. Nutrition., 29(4): 611618. doi:10.1016/j.nut.2012.12.018.

Schaffer SW, Ju Jong C, Kc R, Azuma J. 2010. Physiological roles of taurine in heart and muscle. Journal of Biomedical Science., 17(Suppl 1): S2. doi:10.1186/1423-0127-17-s1-s2.

Schaffer SW, Shimada K, Jong CJ, Ito T, Azuma J, Takahashi K. 2014. Effect of taurine and potential interactions with caffeine on cardiovascular function. Amino Acids., 46(5): 1147-1157. doi:10.1007/s00726-014-1708-0.

Schwingshackl L, Hoffmann G. 2013. Long-term effects of lowfat diets either low or high in protein on cardiovascular and metabolic risk factors: a systematic review and metaanalysis. Nutrition Journal., 12(48).

Selcen Salmanoglu D, Gurpinar T, Vural K, Ekerbicer N, Darıverenli E, Var A. 2016. Melatonin and L-carnitin improves endothelial disfunction and oxidative stress in Type 2 diabetic rats. Redox Biology., 8: 199-204. doi:10.1016/j.redox.2015.11.007.

Seldin MM, Meng Y, Qi H, Zhu W, Wang Z, Hazen SL, Lusis AJ, Shih DM. 2016. Trimethylamine N-oxide promotes vascular inflammation through signaling of mitogenactivated protein kinase and nuclear factor- $\mathrm{\kappa} B$. Journal of the American Heart Association., 5(2): e002767. doi:10.1161/jaha.115.002767.
Semba RD, Gebauer SK, Baer DJ, Sun K, Turner R, Silber HA, Talegawkar S, Ferrucci L, Novotny JA. 2014. Dietary intake of advanced glycation end products did not affect endothelial function and inflammation in healthy adults in a randomized controlled trial. Journal of Nutrition. 144(7): 1037-1042. doi:10.3945/jn.113.189480.

Sharif Kashani B, Tahmaseb Pour P, Malekmohammad M, Behzadnia N, Sheybani-Afshar F, Fakhri M, Chaibakhsh S, Naghashzadeh F, Aidenlou S. 2014. Oral 1-citrulline malate in patients with idiopathic pulmonary arterial hypertension and Eisenmenger Syndrome: a clinical trial. J Cardiol., 64(3), 231-235. doi:10.1016/j.jjcc.2014.01.003.

Shay CM, Gooding HS, Murillo R, Foraker R. 2015. Understanding and improving cardiovascular health: An update on the American Heart Association's Concept of cardiovascular health. Prog Cardiovasc Dis., 58(1): 41-49. doi:10.1016/j.pcad.2015.05.003.

Stubbs JR, House JA, Ocque AJ, Zhang S, Johnson C, Kimber C, Schmidt K, Gupta A, Wetmore JB, Nolin TD, Spertus JA, $\mathrm{Yu}$ AS. 2015. Serum trimethylamine-N-oxide is elevated in CKD and correlates with coronary atherosclerosis burden. Journal of the American Society of Nephrology., 27(1): 305313. doi:10.1681/asn.2014111063.

Sun H, Lu G, Ren S, Chen J, Wang Y. 2011. Catabolism of branched-chain amino acids in heart failure: Insights from genetic models. Pediatric Cardiology., 32(3): 305-310. doi:10.1007/s00246-010-9856-9.

Tahavorgar A, Vafa M, Shidfar F, Gohari M, Heydari I. 2015. Beneficial effects of whey protein preloads on some cardiovascular diseases risk factors of overweight and obese men are stronger than soy protein preloads - A randomized clinical trial. Journal of Nutrition \& Intermediary Metabolism., 2(3-4): 69-75. doi:10.1016/j.jnim.2015.08.002.

Tamanna N, Mahmood N. 2015. Food processing and maillard reaction products: Effect on human health and nutrition. International Journal of Food Science., 2015: 1-6. doi:10.1155/2015/526762.

Tang WHW, Hazen SL. 2014. The contributory role of gut microbiota in cardiovascular disease. Journal of Clinical Investigation., 124(10): 4204-4211. doi:10.1172/jci72331.

Tang WHW, Wang Z, Kennedy DJ, Wu Y, Buffa JA, AgatisaBoyle B, Li XS, Levison BS, Hazen SL. 2014. Gut microbiota-dependent trimethylamine $\mathrm{N}$-oxide (TMAO) pathway contributes to both development of renal insufficiency and mortality risk in chronic kidney disease. Circulation Research., 116(3): 448-455. doi:10.1161/circresaha.116.305360.

Tantini B, Fiumana E, Cetrullo S, Pignatti C, Bonavita F, Shantz LM, Giordano E, Muscari C, Flamigni F, Guarnieri C. 2006. Involvement of polyamines in apoptosis of cardiac myoblasts in a model of simulated ischemia. Journal of Molecular and Cellular Cardiology., 40(6): 775-782. doi:10.1016/j.yjmcc.2006.03.002.

Tessier FJ, Birlouez-Aragon I. 2010. Health effects of dietary Maillard reaction products: the results of ICARE and other studies. Amino Acids., 42(4): 1119-1131. doi:10.1007/s00726-010-0776-z.

van Dijk SC, Enneman AW, Swart KMA, van Wijngaarden JP, Ham AC, Brouwer-Brolsma EM, van der Zwaluw NL, Blom HJ, Feskens EJ, Geleijnse JM, van Schoor NM, DhonuksheRutten RAM, de Jongh RT, Lips P, de Groot LCPGM, Uitterlinden AG, Smulders YM, van den Meiracker AH, Mattace Raso FUS, van der Velde N. 2015. Effects of 2-year vitamin B12 and folic acid supplementation in hyperhomocysteinemic elderly on arterial stiffness and cardiovascular outcomes within the B-PROOF trial. Journal of Hypertension., 33(9): 1897-1906. doi:10.1097/hjh.0000000000000647. 
van Tienhoven-Wind L, Dullaart R. 2015. Low-normal thyroid function and novel cardiometabolic biomarkers. Nutrients., 7(2): 1352-1377. doi:10.3390/nu7021352.

van Zanten AR. 2015. Glutamine and antioxidants: status of their use in critical illness. Curr Opin Clin Nutr Metab Care., 18(2): 179-186. doi:10.1097/MCO.0000000000000152.

Vinknes KJ, Dekker JM, Drevon CA, Refsum H, Nurk E, Nijpels G, Stehouwer CDA, Teerlink T, Tell GS, Nygård O, Vollset SE, Ueland PM, Elshorbagy AK. 2013. Plasma sulfur amino acids and stearoyl-CoA desaturase activity in two caucasian populations. Prostaglandins, Leukotrienes and Essential Fatty Acids (PLEFA)., 89(5): 297-303. doi:10.1016/j.plefa.2013.09.007.

Wang W, Wu Z, Dai Z, Yang Y, Wang J, Wu G. 2013. Glycine metabolism in animals and humans: implications for nutrition and health. Amino Acids., 45(3): 463-477. doi:10.1007/s00726-013-1493-1.

Wang Z, Klipfell E, Bennett BJ, Koeth R, Levison BS, DuGar B, Feldstein AE, Britt EB, Fu X, Chung YM, Wu Y, Schauer P, Smith JD, Allayee H, Tang WHW, DiDonato JA, Lusis AJ, Hazen SL. 2011. Gut flora metabolism of phosphatidylcholine promotes cardiovascular disease. Nature., 472(7341): 57-63. doi:10.1038/nature09922.

WHO. 2014. Global Status Report on NoncommunicableDiseases. http://www.who.int/nmh/publications/ncd-status-report2014/en/, (erişim tarihi: 13.06.2016).

WHO. 2015. Health in 2015 from Millennium Development to Sustainable Development Goal. http://www.who.int/gho/publications/mdgs-sdgs/en/, (erişim tarihi: 13.06.2016).

Wilson A, McLean C, Kim RB. 2016. Trimethylamine-N-oxide. Current Opinion in Lipidology., 27(2): 148-154. doi:10.1097/mol.0000000000000274.
Yang Y, Wu Z, Meininger CJ, Wu G. 2015. 1-Leucine and NOmediated cardiovascular function. Amino Acids., 47(3): 435-447. doi:10.1007/s00726-014-1904-y.

Yu Z, Yin Y, Zhao W, Chen F, Liu J. 2014. Application and bioactive properties of proteins and peptides derived from hen eggs: opportunities and challenges. J Sci Food Agric., 94(14): 2839-2845. doi:10.1002/jsfa.6670.

Zambrowicz A, Dąbrowska A, Bobak L, Szołtysik M. 2014. Egg yolk proteins and peptides with biological activity. Postepy Hig Med Dosw., 68: 1524-1529.

Zeeshan H, Lee G, Kim HR, Chae HJ. 2016. Endoplasmic reticulum stress and associated ROS. International Journal of Molecular Sciences., $17(3)$ : 327. doi:10.3390/ijms 17030327.

Zhu W, Gregory Jill C, Org E, Buffa Jennifer A, Gupta N, Wang Z, Li L, Fu X, Wu Y, Mehrabian M, Sartor RB, McIntyre Thomas M, Silverstein Roy L, Tang WHW, DiDonato Joseph A, Brown JM, Lusis Aldons J, Hazen Stanley L. 2016. Gut microbial metabolite TMAO enhances platelet hyperreactivity and thrombosis risk. Cell., 165(1): 111-124. doi:10.1016/j.cell.2016.02.011.

Zulli A. 2011. Taurine in cardiovascular disease. Current Opinion in Clinical Nutrition and Metabolic Care., 14(1): 57-60. doi:10.1097/MCO.0b013e328340d863.

Zuo H, Ueland PM, Ulvik A, Eussen SJPM, Vollset SE, Nygård O, Midttun $\varnothing$, Theofylaktopoulou D, Meyer K, Tell GS. 2016. Plasma biomarkers of inflammation, the kynurenine pathway, and risks of all-cause, cancer, and cardiovascular disease mortality. American Journal of Epidemiology., 183(4): 249-258. doi:10.1093/aje/kwv242. 